\title{
Differences in some developmental features between Toxoplasma gondii-seropositive and seronegative school children
}

\author{
Hanna Mizgajska-Wiktor ${ }^{1}$, Wojciech Jarosz ${ }^{1}$, Izabela Andrzejewska ${ }^{2}$, Magdalena Krzykała ${ }^{3}$, Jarosław \\ Janowski $^{4}$ and Maria Kozlowska ${ }^{5}$ \\ ${ }^{1}$ Department of Biology and Environmental Protection, University School of Physical Education, Poznań, Poland; \\ ${ }^{2}$ Chair and Department of Biology and Medical Parasitology, University of Medical Sciences, Poznań, Poland; \\ ${ }^{3}$ Chair of Anthropology and Biometry, University School of Physical Education, Poznań, Poland; \\ ${ }^{4}$ Chair of Theory and Methodology of Sport, University School of Physical Education, Poznań, Poland; \\ ${ }^{5}$ Department of Mathematical and Statistical Methods, Poznań University of Life Sciences, Poznań, Poland
}

\begin{abstract}
Knowledge about the influence of latent toxoplasmosis on development and general biological condition of children is scant and thus the aim of the present study was to investigate these aspects in some detail. We compare school children in rural area seropositive and seronegative to the apicomplexan parasite Toxoplasma gondii (Nicolle et Manceaux, 1908) in terms of their developmental age, body mass and body height, physical fitness and end-of-term grades. Additionally, we evaluated the risk factors of infection with $T$. gondii such as the presence of cats in the household and eating raw meat products. With IFAT and ELISA tests, the prevalence of anti-Toxoplasma antibodies was 41\% (190 children examined) and the rate of infection was higher in girls (44\%) than in boys (36\%). No significant differences were observed in morphological features and physical fitness of examined children. In girls the level of developmental age measured with electrophoretical mobility of nuclei method was significantly higher and school performance significantly lower for those infected with Toxoplasma than for uninfected; this finding was particularly intriguing. Only boys who ate raw meat products were more likely to be seropositive. The study provides some new information on gender differences in reaction to Toxoplasma infection.
\end{abstract}

Keywords: toxoplasmosis, developmental age, physical fitness, risk factors, children development

This article contains supporting information (Fig. S1-S2) online at http://folia.paru.cas.cz/suppl/2013-60-5-416.pdf

Toxoplasmosis caused by ubiquitous and polyxenous protist (apicomplexan) Toxoplasma gondii (Nicolle et Manceaux, 1908) is a common human zoonosis. The percentage of Toxoplasma-seropositive people in the population usually reaches a few dozen and is lower in countries with a cool climate (Tenter et al. 2000). Man, which may serve as an intermediate host, can be infected with oocysts from soil contaminated with cat faeces, cysts contained in raw meat or vertically, with tachyzoites passed to the foetus via the placenta. Cysts of T. gondii most often reach neural and muscular tissues of an intermediate host and survive there in the dormant form of bradyzoite for several years (Dubey 1998).

Most cases of infection with $T$. gondii are asymptomatic or proceed with mild symptoms, but some cause serious consequences such as abortion or congenital disease (Tenter et al. 2000). Seroprevalence and pathogenic changes in the human body in symptomatic toxoplasmosis have been extensively described, but the data on the influence of latent toxoplasmosis on biological condition of the host are rather scarce. The first published report concerned experimental animals and showed that the presence of $T$. gondii in rodents made them calmer and less afraid of novelty (Hutchinson et al. 1980, Hay et al. 1984, Webster et al. 1994).

The psycho-behavioral sphere of the infected people was studied and it was also observed that Toxoplasmaseropositive people had personality changes and a decrease of psychomotor performance; there were even suggestions that toxoplasmosis could provoke some cases of schizophrenia (Flegr et. al. 1996, 2000, 2002, 2003, Havlíček et al. 2001, Torrey and Yolken 2003). However, significant relationship between $T$. gondii infection and cognitive function was not found in other studies (Thomas et al. 2004).

All these results were so intriguing that they became an impulse for a further study of the subject. We were interested in significance of latent toxoplasmosis for the 
development of children and their general biological condition. For this purpose we undertook a complex study of all schoolchildren in the village of Grzebienisko (western Poland). The prevalence of $T$. gondii antibodies was determined and then we compared developmental age, body mass and height, muscular strength, flexibility, agility, speed, aerobic capacity and performance at school in seropositive and seronegative children. Additionally, we evaluated the risk factors of the infection by asking children about the presence of cats in the household and about eating raw meat products. Results of the study should tell us more about the role of environmental factors in child development and bring more information about the relationship between Toxoplasma and its human intermediate host.

\section{MATERIALS AND METHODS}

\section{Children tested}

The study was conducted in the Polish rural village of Grzebienisko situated $40 \mathrm{~km}$ west of Poznań, Wielkopolska. In the only local primary school of the village all children aged $8-16$ years were included in the study, which took an entire week to complete. The number of children examined varied between 159 and 204 for various tests. The prevalence of Toxoplasma antibodies was determined for 190 children, developmental age, body mass and body height for 199, physical fitness and end-of-term grades in individual subjects for 204; 152 children were questioned about the owning of cats and eating raw meat products. For statistical analysis, only children tested serologically, i.e. 190 persons, were included. Before the tests, a meeting with parents was held to inform them of the aim and significance of the study and written consents for sampling blood and epithelium from the mouth of the children were obtained.

\section{Serological tests}

Toxoplasmosis was diagnosed in venous blood samples, which were subsequently centrifuged to obtain serum. In the sera IgG Toxoplasma antibodies were detected with Immune Fluorescent Antibody Technique (IFAT) according to Goldman (1957). The titre of antibodies was measured in dilutions between $1: 8$ to $1: 262144$. were considered with titres lower than $1: 16$ as seronegative. Additionally, 20 samples (11 girls and 9 boys) with titres $1: 1024$ and higher (Table 1) were tested for detecting acute toxoplasmosis using specific IgM antibodies with applying both, IFAT and ELISA tests (Bordier Affinity Products, Crissier, Switzerland).

\section{Developmental age}

The calendar age of children was determined anthropologically on the decimal scale (e.g. 8.50-9.49 means 9 years old). The developmental age was assessed with the universal test electrophoretical mobility of nuclei (EMN), which measures nucleus mobility in a changing electrical field (Shakhbazov et al. 1986, 1996). To this purpose, epithelial cells were collected from the oral cavity and put into the Eppendorf tube containing $0.9 \%$ sodium chloride solution $(\mathrm{NaCl})$ for further laboratory testing. The index was determined by calculating the proportion between cells with a mobile nucleus and those where the nucleus did not pulsate. The Biotest apparatus, which automatically calculates the EMN index for 100 cells observed under the microscope, was used. The average EMN for humans is consist-
Table 1. Prevalence of Toxoplasma-antibodies in schoolchildren from the village of Grzebienisko, Poland according to IFAT test and the titres.

\begin{tabular}{lccc}
\hline \multirow{2}{*}{$\begin{array}{l}\text { Titres } \\
\text { IgG) }\end{array}$} & \multicolumn{3}{c}{$\mathrm{n}(\%)$ positive } \\
\cline { 2 - 4 } & total $(\mathrm{n}=190)$ & girls $(\mathrm{n}=112)$ & boys $(\mathrm{n}=78)$ \\
\hline $1: 16$ & $22(12)$ & $15(13)$ & $7(9)$ \\
$1: 64$ & $22(12)$ & $12(11)$ & $10(13)$ \\
$1: 256$ & $13(7)$ & $11(10)$ & $2(3)$ \\
$1: 1024$ & $9(5)$ & $5(5)$ & $4(5)$ \\
$1: 2048$ & $7(4)$ & $4(4)$ & $3(4)$ \\
$1: 4096$ & $2(1)$ & $1(1)$ & $1(1)$ \\
$1: 16384$ & $1(1)$ & $1(1)$ & - \\
$1: 262144$ & $1(1)$ & - & $1(1)$ \\
\hline Total & $77(41)$ & $49(44)$ & $28(36)$ \\
\hline
\end{tabular}

ent with the general model of the human development, i.e. its value grows significantly during early ontogenesis to reach the peak around the age of 17 and later declines (Czapla and Cieślik 1998).

\section{Body mass and body height}

Body height and body mass were determined using a standardized procedure. The height was measured with a stadiometer to the nearest $0.1 \mathrm{~cm}$ and the body mass with a beam-balance scale to the nearest $0.1 \mathrm{~kg}$. Biological age of body height, body mass and EMN were calculated according to the specific formula of Marti (Stinson et al. 2000): WBK $=$ WMD + ([X - MD]/[MG - MD]). Abbreviation: WBK - biological age of some characteristic, WMD - age of lower range limit for a given characteristic, $\mathrm{X}$ - measured value of a given characteristic, MD - mean of lower range limit for a given characteristic, and $\mathrm{MG}$ - mean of upper range limit for a given characteristic.

\section{Physical fitness}

Physical fitness was determined with a battery of tests of muscular strength, flexibility, agility, speed and aerobic capacity according to the procedure described in the paper of Jarosz et al. (2010). It was conducted at the school sport hall after an instruction, demonstration and a ten-minute warm-up conducted by a physical education teacher. Muscular strength was tested by vertical jump, flexibility by measuring the depth of the forward bend (sit and reach test), agility (coordination) by measuring the time of a triple run around an eight-shaped track, and speed by a five-metre run. Aerobic capacity was tested with a fiveminute Montoye step test (Wachowski et al. 1987). The capacity index, expressed in points, was calculated with the following formula $\mathrm{E}=(\mathrm{t} \times 100) /(5.5 \times \mathrm{p})$. Abbreviation: $\mathrm{E}-$ capacity index, $\mathrm{t}$ - time of exercise (in seconds) and $\mathrm{p}$ - pulse value after the exercise.

\section{Questionnaire}

Children were asked about owning cats in the household and eating raw meat products. Then for every child, on the basis of their school reports, a mean of the end-of-term grades was calculated to be included in the questionnaire.

\section{Statistical analysis}

The data were entered into a spreadsheet and then analysed with Statistica ver. 9.1 software (StatSoft). For the calculations two groups were distinguished: seropositive (titre between $1: 16$ and $1: 262144$ ) and seronegative (titre below $1: 16$ ). The association of morphological features, physical fitness abilities 


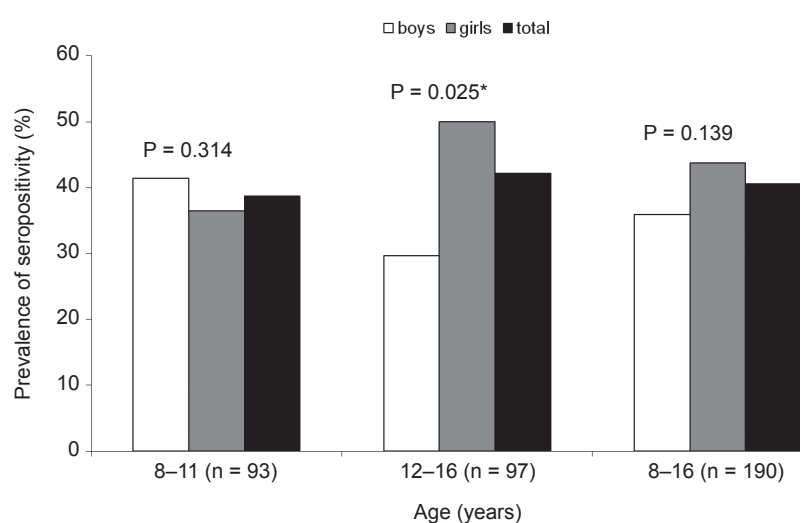

Fig. 1. Prevalence of Toxoplasma antibodies ( $\mathrm{IgG})$ in younger (8-11 years) and older (12-16 years) school children in the village of Grzebienisko, Poland. The rate of infection among girls was higher than among boys, but the difference was significant $\left(^{*}\right)$ only in the older group $(\mathrm{P}=0.025)$.

and school performance with Toxoplasma seropositivity was analysed by multivariate analysis of covariance (MANCOVA) as well as by simple analysis for each feature (ANCOVA). Sex, age and Toxoplasma seropositivity were set as independent variables, and morphological features and physical fitness abilities as dependent variables (age was set as confounding variable). For analyses of covariance, adjusted means of variables were used. Association of EMN and EMN biological age with Toxoplasma seropositivity was analysed by MANOVA/ANOVA tests with sex and seropositivity as independent variables. When necessary, pairwise comparison of adjusted means was performed with the post-hoc HSD Tukey test.

Additionally, the partial Kendall tau correlation test was used for analyses of correlation between two variables (seropositivity and each of morphological features, developmental age, each of physical fitness abilities, school performance and risk factors - cat possession and eating raw meat products) with control of an correlation of age. The test was performed for girls and boys separately, as well as for all examined children. The same test was used for Toxoplasma-seropositive subjects only, and correlation of morphological features, developmental age as well as physical fitness abilities and school performance variables with the level of IFAT titre were searched.

Logistic regression model (logit) was used for analysis of association between Toxoplasma seropositivity and risk factors, i.e. cat possession (number of cats in the household) and the frequency of eating raw meat products (never, rarely or often). The analysis was performed separately for boys and girls. Statistica software (StatSoft) was used for statistical analysis. The computation of the partial Kendall tau correlation test was performed in the ready spreadsheet as described in the paper of Flegr (2010).

\section{RESULTS}

\section{Seroprevalence}

Out of 190 children examined in the village of Grzebienisko, 77 (41\%) were seropositive with IgG-antibodies titres between $1: 16$ and $1: 262144$. Prevalence of Tox-
Table 2. Seroprevalence of Toxoplasma antibodies (IgG) in boys and girls of different age categories from the village of Grzebienisko, Poland according to IFAT test.

\begin{tabular}{ccccccc}
\hline \multirow{2}{*}{$\begin{array}{c}\text { Age } \\
\text { (years })\end{array}$} & \multicolumn{2}{c}{ Boys } & \multicolumn{2}{c}{ Girls } & \multicolumn{2}{c}{ Total } \\
\cline { 2 - 7 } & $\begin{array}{c}\text { examined } \\
(\mathrm{n})\end{array}$ & $\begin{array}{c}\text { positive } \\
(\%)\end{array}$ & $\begin{array}{c}\text { examined } \\
(\mathrm{n})\end{array}$ & $\begin{array}{c}\text { positive } \\
(\%)\end{array}$ & $\begin{array}{c}\text { examined } \\
(\mathrm{n})\end{array}$ & $\begin{array}{c}\text { positive } \\
(\%)\end{array}$ \\
\hline 8 & 9 & 44 & 7 & 29 & 16 & 38 \\
9 & 12 & 42 & 11 & 27 & 23 & 35 \\
10 & 9 & 67 & 19 & 47 & 28 & 54 \\
11 & 11 & 18 & 15 & 33 & 26 & 27 \\
12 & 10 & 40 & 12 & 58 & 22 & 50 \\
13 & 7 & 27 & 20 & 35 & 27 & 33 \\
14 & 12 & 33 & 17 & 47 & 29 & 41 \\
15 & 7 & 14 & 10 & 80 & 17 & 53 \\
16 & 1 & 0 & 1 & 0 & 2 & 0 \\
$8-16$ & 78 & 36 & 112 & 44 & 190 & 41 \\
\hline
\end{tabular}

oplasma antibodies among girls was higher (44\%) than among boys ( $36 \%$ ) and did not increase with age (Table 1$)$. Prevalence of seropositivity decreased with the growing dilution of titres and high titres of antibodies (1: 1024 and more) were observed only among 20 children examined (11\%). One 14 years old girl and two boys, 10 and 11 years old, were found to have an acute toxoplasmosis on the basis of their high level of IgG (IFAT test $-1: 1024$, $1: 16384$ and $1: 262144$; ELISA test $-1: 100,1: 400$ and $1: 3200$, respectively) and the presence of IgM Toxoplasma antibodies (IFAT test $-1: 40,1: 40$ and $1: 80$; ELISA test $-1: 100,1: 200$ and $1: 1600$, respectively). Those children were recommended for treatment.

The Toxoplasma seroprevalence was slightly higher for 12-16 year-olds (41\%) than for 8-11 year-olds $(39 \%)$. Among older girls seropositivity was higher than in younger girls (50\% vs 37\%), whereas it was inversely in boys: seropositivity was lower in the older group than in the younger group ( $30 \%$ vs $41 \%)$, but the differences were not statistically significant. A statistically significant difference $(\mathrm{P}=0.025)$ was observed in Toxoplasma seroprevalence between boys and girls in the group of 12-16 year-olds (Fig. 1, see also Table 2).

\section{Developmental age of Toxoplasma-seropositive and seronegative children}

The positive correlation between Toxoplasma seropositivity and the level of developmental age was observed among girls. Seropositive girls had significantly higher EMN index $(n=112$, partial tau $=0.189, z=2.964$, $\mathrm{P}=0.003)$ as well as EMN biological age $(\mathrm{n}=112$, partial tau $=0.173, \mathrm{z}=2.712, \mathrm{P}=0.0067)$. Such a phenomenon was observed among boys neither in EMN index $(n=78$, partial tau $=-0.049, \mathrm{z}=-0.638, \mathrm{P}=0.523$ ) nor in $\mathrm{EMN}$ age $(\mathrm{n}=78$, partial tau $=-0.040, \mathrm{z}=-0.517, \mathrm{P}=0.604)$.

When Toxoplasma-seropositive children were considered, no correlation was found between EMN and IFAT titre level among girls $(n=49$, partial tau $=-0.031$, 
Table 3. Results of the partial Kendall tau correlation test for Toxoplasma seropositivity, the level of IFAT titre and morphological features in boys and girls.

\begin{tabular}{lcccccc}
\hline & \multicolumn{3}{c}{ Boys } & \multicolumn{3}{c}{ Girls } \\
\cline { 2 - 7 } & Tau & $\mathrm{z}$ & $\mathrm{P}$ & Tau & $\mathrm{z}$ & $\mathrm{P}$ \\
\hline Seropositivity & \multicolumn{3}{c}{$\mathrm{N}=78$} & & \multicolumn{3}{c}{$\mathrm{N}=112$} \\
\cline { 2 - 7 } Body mass & -0.058 & -0.748 & 0.454 & 0.124 & 1.958 & 0.0502 \\
Body mass age & -0.058 & -0.745 & 0.456 & 0.119 & 1.865 & 0.062 \\
Body height & -0.082 & -1.062 & 0.288 & 0.118 & 1.851 & 0.064 \\
Body height age & -0.081 & -1.045 & 0.296 & 0.109 & 1.709 & 0.087 \\
IFAT titre & & $\mathrm{N}=28$ & & & $\mathrm{~N}=49$ & \\
Body mass & -0.108 & -0.809 & 0.419 & 0.053 & 0.537 & 0.591 \\
Body mass age & -0.108 & -0.809 & 0.419 & 0.048 & 0.487 & 0.627 \\
Body height & -0.227 & -1.698 & 0.090 & -0.079 & -0.801 & 0.423 \\
Body height age & -0.227 & -1.698 & 0.090 & -0.090 & -0.916 & 0.360 \\
\hline
\end{tabular}

$\mathrm{z}=-0.312, \mathrm{P}=0.755$ for $\mathrm{EMN}$ index and partial tau $=-0.005, \mathrm{z}=-0.048, \mathrm{P}=0.962$ for $\mathrm{EMN}$ age) and boys $(\mathrm{n}=28$, partial tau $=0.031, \mathrm{z}=0.231, \mathrm{P}=0.817$ for EMN index and partial tau $=0.026, \mathrm{z}=0.191, \mathrm{P}=0.849$ for EMN age).

Multivariate analysis of variance test (MANOVA) with sex and Toxoplasma seropositivity as independent variables, and with EMN index and EMN biological age as dependent variables showed the significant correlation between Toxoplasma seropositivity $\times$ sex interaction and the EMN values of examined subjects $\left(\mathrm{F}_{2,186}=4.244\right.$, $\mathrm{P}=0.0158)$. The correlations between sex and Toxoplasma seropositivity were not significant $\left(\mathrm{F}_{2,186}=0.177\right.$, $\mathrm{P}=0.838$ and $\mathrm{F}_{2,186}=0.863, \mathrm{P}=0.424$, respectively).

Results of ANOVA test were significant for correlation of Toxoplasma seropositivity $\times$ sex interaction and the EMN index $\left(\mathrm{F}_{1,187}=5.767, \mathrm{P}=0.0173\right)$. The same correlation was nearly significant for EMN biological age $\left(\mathrm{F}_{1,187}=3.750, \mathrm{P}=0.0543\right)$. Post hoc comparisons using the Tukey HSD test confirmed that the means of EMN index differ significantly $(\mathrm{P}<0.05)$ between seropositive and seronegative girls (54.22 and 47.94, respectively). No such difference was found between seropositive and seronegative boys (49.32 and 51.84, respectively).

\section{Morphological features of Toxoplasma-seropositive and seronegative children}

Morphological features differed significantly in examined children when girls and boys were compared, but there were no significant differences between seropositive and seronegative boys and girls with regards to the body height, body mass, biological age of body height and biological age of body mass. It should be mentioned that the influence of seropositivity on the morphological features in girls group approached the level of significance in the partial Kendall tau correlation test: body height $(P=0.0641)$, body height age $(P=0.0874)$, body mass $(\mathrm{P}=0.0502)$ and body mass age $(\mathrm{P}=0.0622)(\mathrm{Ta}-$ ble 3 ). Morphological features did not correlate with the
Table 4. Age-adjusted means of morphological features and their biological age in combinations with sex and Toxoplasma seropositivity (Toxo) together with results of ANCOVA tests of relation between seropositivity/seropositivity and sex of children.

\begin{tabular}{|c|c|c|c|c|c|c|c|}
\hline Variable & Sex & Toxo & Mean & SE & \multicolumn{2}{|c|}{$-95.00 \% 95.00 \%$} & $\mathrm{~N}$ \\
\hline \multirow[t]{5}{*}{$\begin{array}{l}\text { Body height } \\
{[\mathrm{cm}]}\end{array}$} & \multicolumn{7}{|c|}{$\begin{array}{c}\text { ANCOVA }(\text { Toxo }): \mathrm{F}_{1,186}=0.206, \mathrm{P}=0.650 \\
\text { ANCOVA }(\text { Toxo } \times \text { sex }): \mathrm{F}_{1,186}=1.621, \mathrm{P}=0.205\end{array}$} \\
\hline & q & - & 150.46 & 0.94 & 148.60 & 152.33 & 64 \\
\hline & q & + & 152.46 & 1.09 & 150.31 & 154.60 & 49 \\
\hline & $\widehat{0}$ & - & 151.24 & 1.07 & 149.13 & 153.34 & 50 \\
\hline & 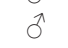 & + & 150.28 & 1.44 & 147.44 & 153.12 & 28 \\
\hline \multirow[t]{5}{*}{$\begin{array}{l}\text { Body height age } \\
\text { [years] }\end{array}$} & \multicolumn{7}{|c|}{$\begin{array}{c}\text { ANCOVA }(\text { Toxo }): \mathrm{F}_{1,186}=0.681, \mathrm{P}=0.410 \\
\text { ANCOVA }(\text { Toxo } \times \text { sex }): \mathrm{F}_{1,186}=1.222, \mathrm{P}=0.270\end{array}$} \\
\hline & 웅 & - & 12.66 & 0.23 & 12.20 & 13.11 & 64 \\
\hline & q & + & 13.20 & 0.27 & 12.68 & 13.72 & 49 \\
\hline & $\delta$ & - & 11.92 & 0.26 & 11.41 & 12.44 & 50 \\
\hline & $\sigma^{1}$ & + & 11.84 & 0.35 & 11.15 & 12.54 & 28 \\
\hline \multirow[t]{5}{*}{$\begin{array}{l}\text { Body mass } \\
{[\mathrm{kg}]}\end{array}$} & \multicolumn{7}{|c|}{$\begin{array}{c}\text { ANCOVA }(\text { Toxo }): \mathrm{F}_{1,186}=2.101, \mathrm{P}=0.149 \\
\text { ANCOVA }(\text { Toxo } \times \text { sex }): \mathrm{F}_{1,186}=0.889, \mathrm{P}=0.347\end{array}$} \\
\hline & q & - & 42.42 & 1.04 & 40.36 & 44.47 & 64 \\
\hline & q & + & 45.45 & 1.20 & 43.08 & 47.81 & 49 \\
\hline & $\hat{\sigma}$ & - & 40.73 & 1.18 & 38.41 & 43.05 & 50 \\
\hline & $\hat{\sigma}$ & + & 41.36 & 1.58 & 38.23 & 44.48 & 28 \\
\hline \multirow[t]{5}{*}{$\begin{array}{l}\text { Body mass age } \\
\text { [years] }\end{array}$} & \multicolumn{7}{|c|}{$\begin{array}{c}\text { ANCOVA }(\text { Toxo }): \mathrm{F}_{1,186}=0.977, \mathrm{P}=0.324 \\
\text { ANCOVA }(\text { Toxo } \times \text { sex }): \mathrm{F}_{1,186}=0.917, \mathrm{P}=0.339\end{array}$} \\
\hline & q & - & 11.99 & 0.25 & 11.50 & 12.48 & 64 \\
\hline & q & + & 12.58 & 0.29 & 12.02 & 13.15 & 49 \\
\hline & $\sigma^{2}$ & - & 11.38 & 0.28 & 10.82 & 11.94 & 50 \\
\hline & $\hat{0}$ & + & 11.39 & 0.38 & 10.63 & 12.14 & 28 \\
\hline
\end{tabular}

Table 5. Results of the partial Kendall tau correlation test for Toxoplasma seropositivity, the level of IFAT titre and physical fitness abilities in boys and girls.

\begin{tabular}{lcccccc}
\hline & \multicolumn{3}{c}{ Boys } & \multicolumn{3}{c}{ Girls } \\
\cline { 2 - 7 } & Tau & $\mathrm{Z}$ & $\mathrm{P}$ & $\mathrm{Tau}$ & $\mathrm{z}$ & $\mathrm{P}$ \\
\hline Seropositivity & \multicolumn{3}{c}{$\mathrm{N}=75$} & & \multicolumn{3}{c}{$\mathrm{N}=110$} \\
\cline { 2 - 7 } Speed & -0.030 & -0.080 & 0.7041 & 0.044 & 0.681 & 0.496 \\
Flexibility & 0.041 & 0.517 & 0.6055 & 0.065 & 1.002 & 0.316 \\
Agility & 0.070 & 0.886 & 0.3756 & -0.026 & -0.402 & 0.687 \\
Strength & -0.062 & -0.785 & 0.4323 & 0.013 & 0.204 & 0.838 \\
Aerobic capacity & 0.096 & 1.216 & 0.2238 & -0.055 & -0.858 & 0.391 \\
IFAT titre & & $\mathrm{N}=28$ & & & $\mathrm{~N}=49$ & \\
Speed & 0.173 & 1.291 & 0.1967 & -0.060 & -0.605 & 0.545 \\
Flexibility & -0.086 & -0.644 & 0.5193 & 0.064 & 0.651 & 0.515 \\
Agility & 0.067 & 0.497 & 0.6189 & -0.075 & -0.764 & 0.445 \\
Strength & -0.149 & -1.115 & 0.2651 & 0.055 & 0.561 & 0.575 \\
Aerobic capacity & -0.094 & -0.703 & 0.4819 & -0.090 & -0.915 & 0.356 \\
\hline
\end{tabular}

level of IFAT titre either among seropositive girls or seropositive boys (Table 3 ).

Multivariate analysis of covariance test (MANCOVA) with sex, age and Toxoplasma seropositivity as independent variables (age was set as covariate) and morphological features as dependent variables showed no significant correlation between toxoplasmosis and the morphology of examined subjects $\left(\mathrm{F}_{4,183}=1.337, \mathrm{P}=0.2577\right)$. The 


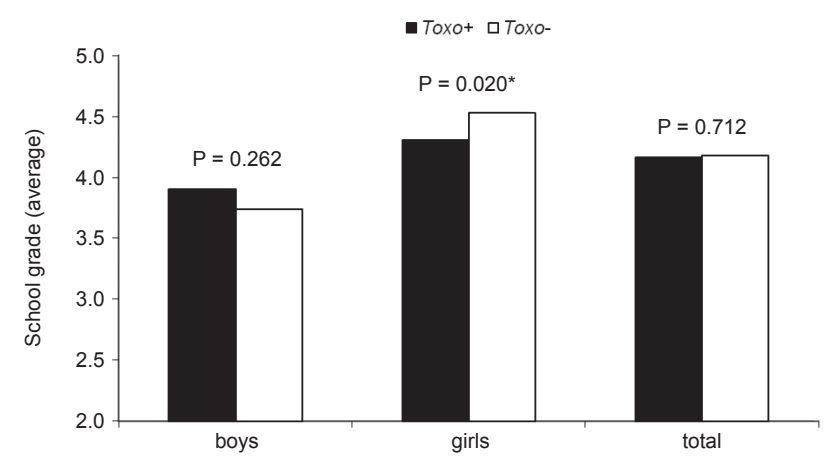

Fig. 2. Comparison of end-of-term grades between Toxoplasma seropositive and Toxoplasma seronegative children. Girls had higher grades than boys, but seropositive and seronegative children had similar grades at school. Seropositive girls had significantly $\left(^{*}\right)$ lower mean grades than seronegative ones $(\mathrm{P}=0.02)$.

seropositivity $\times$ sex interaction was also not significant $\left(\mathrm{F}_{4,183}=0.411, \mathrm{P}=0.8008\right)$. The correlation between sex and morphological features was highly significant $\left(\mathrm{F}_{4,183}=14.539, \mathrm{P}<0.0001\right)$. Results of simple analysis for each feature when the correlation of seropositivity and seropositivity $\times$ sex interaction were considered were not significant (Table 4). ANCOVA test was significant only for the correlation between sex on body mass $\left(F_{1,183}=5.190, P=0.024\right)$, biological age of body mass $\left(\mathrm{F}_{1,183}=8.802, \mathrm{P}=0.003\right)$ and biological age of body height $\left(\mathrm{F}_{1,183}=13.813, \mathrm{P}=0.0003\right)$.

\section{Physical fitness of Toxoplasma-seropositive and seronegative children}

Physical fitness differed in examined children when girls and boys were compared, but no significant differences were found between the Toxoplasma-seropositive and seronegative, either boys or girls when speed, flexibility, agility, strength and aerobic capacity were analysed with the partial Kendall tau correlation test (Table 5). The level of IFAT titre also did not correlate with each of physical fitness abilities, both, among seropositive boys and seropositive girls (Table 5).

MANCOVA test with sex and toxoplasmosis as independent variables, age as covariate and physical fitness abilities as dependent variables showed no significant correlation between toxoplasmosis and the physical fitness of examined subjects $\left(\mathrm{F}_{5,170}=0.444, \mathrm{P}=0.817\right)$. The seropositivity $\times$ sex interaction was also not significant $\left(\mathrm{F}_{5,170}=0.816, \mathrm{P}=0.540\right)$. Correlation between sex and physical fitness abilities was highly significant $\left(F_{5,170}=6.386, P=0.00002\right)$. Results of simple analysis for each ability (correlation of seropositivity and seropositivity $\times$ sex interaction) were not significant (Table 6). ANCOVA test was significant only for correlation between sex and speed $\left(\mathrm{F}_{1,174}=9.319, \mathrm{P}=0.003\right)$, flexibility $\left(\mathrm{F}_{1,174}=4.465\right.$, $\mathrm{P}=0.036)$, strength $\left(\mathrm{F}_{1,174}=5.000, \mathrm{P}=0.027\right)$ and aerobic capacity $\left(\mathrm{F}_{1,174}=12.436, \mathrm{P}=0.0005\right)$.
Table 6. Age-adjusted means of physical fitness abilities and school performance in combinations with sex and Toxoplasma seropositivity (Toxo) together with results of ANCOVA tests of relation between seropositivity/seropositivity and sex of children.

\begin{tabular}{|c|c|c|c|c|c|c|c|}
\hline Variable & Sex & Toxo & Mean & SE & \multicolumn{2}{|c|}{$-95,00 \% 95,00 \%$} & $\mathrm{~N}$ \\
\hline \multirow[t]{5}{*}{$\begin{array}{l}\text { Speed } \\
\text { [s] }\end{array}$} & \multicolumn{7}{|c|}{$\begin{array}{c}\text { ANCOVA }(\text { Toxo }): \mathrm{F}_{1,174}=1.442, \mathrm{P}=0.231 \\
\text { ANCOVA }(\text { Toxo } \times \text { sex }): \mathrm{F}_{1,174}=2.624, \mathrm{P}=0.107\end{array}$} \\
\hline & 우 & - & 1.290 & 0.014 & 1.262 & 1.318 & 60 \\
\hline & q & + & 1.298 & 0.016 & 1.266 & 1.330 & 47 \\
\hline & 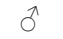 & - & 1.266 & 0.016 & 1.234 & 1.297 & 47 \\
\hline & $\hat{\sigma}$ & + & 1.217 & 0.022 & 1.173 & 1.260 & 25 \\
\hline \multirow[t]{5}{*}{$\begin{array}{l}\text { Agility } \\
{[\mathrm{s}]}\end{array}$} & \multicolumn{7}{|c|}{$\begin{array}{c}\text { ANCOVA }(\text { Toxo }): \mathrm{F}_{1,174}=0.001, \mathrm{P}=0.976 \\
\text { ANCOVA }(\text { Toxo } \times \text { sex }): \mathrm{F}_{1,174}=0.021, \mathrm{P}=0.884\end{array}$} \\
\hline & q & - & 17.79 & 0.22 & 17.34 & 18.23 & 60 \\
\hline & q & + & 17.75 & 0.25 & 17.25 & 18.26 & 47 \\
\hline & $\delta$ & - & 17.52 & 0.25 & 17.02 & 18.02 & 47 \\
\hline & $\delta$ & + & 17.57 & 0.35 & 16.88 & 18.26 & 25 \\
\hline \multirow[t]{5}{*}{$\begin{array}{l}\text { Flexibility } \\
{[\mathrm{cm}]}\end{array}$} & \multicolumn{7}{|c|}{$\begin{array}{l}\text { ANCOVA }(\text { Toxo }): \mathrm{F}_{1,174}=0.064, \mathrm{P}=0.801 \\
\text { ANCOVA }(\text { Toxo } \times \text { sex }): \mathrm{F}_{1,174}=0.129, \mathrm{P}=0.720\end{array}$} \\
\hline & 우 & - & 53.54 & 0.82 & 51.93 & 55.15 & 60 \\
\hline & q & + & 54.15 & 0.93 & 52.32 & 55.99 & 47 \\
\hline & $\hat{\sigma}$ & - & 51.78 & 0.92 & 49.96 & 53.60 & 47 \\
\hline & $\hat{\sigma}$ & + & 51.67 & 1.28 & 49.15 & 54.19 & 25 \\
\hline \multirow[t]{5}{*}{$\begin{array}{l}\text { Strength } \\
{[\mathrm{cm}]}\end{array}$} & \multicolumn{7}{|c|}{$\begin{array}{c}\text { ANCOVA }(\text { Toxo }): \mathrm{F}_{1,174}=0.030, \mathrm{P}=0.863 \\
\text { ANCOVA }(\text { Toxo } \times \text { sex }): \mathrm{F}_{1,174}=0.062, \mathrm{P}=0.803\end{array}$} \\
\hline & 우 & - & 26.88 & 0.66 & 25.58 & 28.18 & 60 \\
\hline & 우 & + & 26.54 & 0.75 & 25.06 & 28.02 & 47 \\
\hline & $\delta$ & - & 28.49 & 0.74 & 27.02 & 29.95 & 47 \\
\hline & $\delta$ & + & 28.55 & 1.03 & 26.52 & 30.58 & 25 \\
\hline \multirow[t]{5}{*}{$\begin{array}{l}\text { Aerobic capacity } \\
\text { [capacity index] }\end{array}$} & \multicolumn{7}{|c|}{$\begin{array}{c}\text { ANCOVA }(\text { Toxo }): \mathrm{F}_{1,174}=0.123, \mathrm{P}=0.726 \\
\text { ANCOVA }(\text { Toxo } \times \text { sex }): \mathrm{F}_{1,174}=0.509, \mathrm{P}=0.476\end{array}$} \\
\hline & ㅇ & - & 48.51 & 1.07 & 46.40 & 50.63 & 60 \\
\hline & 우 & + & 48.03 & 1.22 & 45.63 & 50.43 & 47 \\
\hline & $\delta$ & - & 52.20 & 1.21 & 49.82 & 54.59 & 47 \\
\hline & 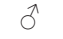 & + & 53.61 & 1.67 & 50.31 & 56.90 & 25 \\
\hline \multirow{5}{*}{$\begin{array}{l}\text { School } \\
\text { performance } \\
\text { [school grades } \\
\text { average] }\end{array}$} & \multicolumn{7}{|c|}{$\begin{array}{c}\text { ANCOVA (Toxo): } \mathrm{F}_{1,186}=0.053, \mathrm{P}=0.814 \\
\text { ANCOVA }(\text { Toxo } \times \text { sex }): \mathrm{F}_{1,186}=1.976, \mathrm{P}=0.161\end{array}$} \\
\hline & q & - & 4.52 & 0.09 & 4.35 & 4.69 & 64 \\
\hline & 우 & + & 4.35 & 0.10 & 4.15 & 4.54 & 49 \\
\hline & $\delta$ & - & 3.73 & 0.10 & 3.54 & 3.93 & 50 \\
\hline & $\delta$ & + & 3.86 & 0.13 & 3.59 & 4.12 & 28 \\
\hline
\end{tabular}

\section{Performance at school of Toxoplasma-seropositive and seronegative children}

In Poland the scale of school grades is from 1 to 6 where the highest performance is 6 and lowest -1 . Girls had higher mean grades than boys (Fig. 2), but seropositive and seronegative children had very similar grades at school (the average of 4.16 and 4.18 , respectively). Seropositive girls had significantly lower mean grades than seronegative ones (4.31 and 4.53 respectively) $(n=112$, partial tau $=-0.149, \mathrm{z}=-2.332, \mathrm{P}=0.0197)$. Seropositive boys, inversely, had higher mean grades than seronegative ones (3.90 and 3.74 respectively), but this difference was not statistically significant $(\mathrm{n}=78$, partial tau $=0.086$, $\mathrm{z}=1.121, \mathrm{P}=0.262$ ) (Fig. 2). School grades did not cor- 
relate with the level of IFAT titre among seropositive girls $(\mathrm{n}=49$, partial tau $=-0.064, \mathrm{z}=-0.649, \mathrm{P}=0.517)$ and boys $(\mathrm{n}=28$, partial tau $=-0.095, \mathrm{z}=-0.706, \mathrm{P}=0.480)$.

Results of ANCOVA for school performance (correlations between seropositivity and seropositivity $\times$ sex interaction) were not significant (Table 4). ANCOVA test was significant only for the relationships of sex and school grades $\left(\mathrm{F}_{1,186}=36.114, \mathrm{P}<0.000001\right)$.

\section{Eating raw meat and owning cats as risk factors of Toxoplasma infection}

Out of 152 children questioned, 40 (26\%) answered that they had never eaten raw meat products. The proportion was $28 \%$ for boys and $23 \%$ for girls. There were no significant differences between the prevalence of Toxoplasma seropositivity in children who eat raw meat and those who do not, both in boys and girls group as well as in all examined children.

Out of 94 girls, $68 \%$ owned at least one cat and out of 58 boys $64 \%$ did. Seropositive children more frequently kept cats in the household $(69 \%)$ than did seronegative ones $(65 \%)$ and this was also true when the gender was taken into consideration. None of the differences, however, was statistically significant.

The logistic regression model (logit) with Toxoplasma seropositivity as dependent variable and two independent variables, cat possession and eating of raw meat products, appeared not to be adequate either for boys $\left(\mathrm{Chi}^{2}=4.6176\right.$, $\mathrm{P}=0.0994)$ or for girls $\left(\mathrm{Chi}^{2}=2.0498, \mathrm{P}=0.3588\right)$. According to the model, boys who eat raw meat products were 2.6 times more likely to be Toxoplasma-seropositive (coefficient $=0.939, \mathrm{SE}=0.463$, odds ratio $=2.557$, $\mathrm{P}=0.0479$ ), but no relation was found between seropositivity and cat possession (coefficient $=0.042, \mathrm{SE}=0.116$, odds ratio $=1.043, \mathrm{P}=0.7163)$. Among girls the opposite situation was observed. Seropositivity was more closely related with cat possession than with eating raw meat products, although the associations were not significant (coefficient $=0.150, \mathrm{SE}=0.106$, odds ratio $=1.162$, $\mathrm{P}=0.161$ and coefficient $=0.067, \mathrm{SE}=0.389$, odds ratio $=1.069, \mathrm{P}=0.864$, respectively) (Figs. S1, S2).

\section{DISCUSSION}

To detect Toxoplasma antibodies in blood samples the IFAT test was used and positive results were confirmed with the commercial ELISA test. Our many years' experience and other authors' suggestions (Rodrigues et al. 2009) indicate that such an approach ensures a good reliability of the results.

In the rural area of Grzebienisko, Toxoplasma seroprevalence among schoolchildren was rather high (41\%) with three children found to be suffering from acute toxoplasmosis. None of the seropositive children, including those with high titres, complained of any symptoms of the disease. This was yet another confirmation of the com- mon opinion that in a majority of cases toxoplasmosis is asymptomatic (Tenter et al. 2000). One 12-year-old seropositive girl (with ELISA IgG titre 1 : 200) was diagnosed, simultaneously, with a high titre of anti-Toxocara antibodies. She lived in a big, rather poor family keeping 7 cats and 5 dogs. We could therefore suppose that the girl had acquired toxoplasmosis by poor hygiene and that the source of infection was soil contaminated with the pets' faeces. Such a view finds support in Jones et al. (2008) where co-occurrence of soil-transmitted Toxocara and T. gondii infections in humans is described.

In the village of Grzebienisko, prevalence of latent toxoplasmosis among children seems to be rather high if compared with other data. For example, 12-34\% seropositivity was found in children in the Wielkopolska region of Poland by Szewczyk-Kramska (1999), 14\% in Bari region of Italy (Leogrande 1992), 12\% in southern Spain (Gutierrez et al. 1996) and 18\% in Union Territory of Chandigarh in India (Mohan et al. 2002). However, it should be remembered that different serological methods and laboratory techniques (with different targeting and sensitivity) were used in those studies; interpretation of results may also have differed between authors.

In contrast to some other studies (Walker et al. 1992, Taylor et al. 1997), in the village of Grzebienisko the prevalence of toxoplasmosis did not increase with age. This could be explained by a small number of children examined in different age groups, although we studied all children in the village; when we grouped them into two age categories, children aged 8-11 versus those aged 12-16 years, Toxoplasma seroprevalence was lower among the younger subjects, but the difference was not statistically significant (Fig. 1). Seropositivity in girls was higher (44\%) than in boys (36\%) and the difference was more noticeable and statistically significant $(\mathrm{P}=0.025)$ in the group of older children (12-16 years). Similar results were obtained by Huldt et al. (1979), who examined 15-16 years old children in Scandinavia and found seroprevalence of $19 \%$ in girls whereas only $14 \%$ in boys.

Our hypothesis to explain such results is that older girls (teenagers) often help their mothers in the kitchen, getting into contact with raw meat, which increases the risk of acquiring toxoplasmosis. Contrary to these results, it was found that adult men are infected more frequently than adult women (e.g. in the Czech Republic - Flegr et al. 2005, and Serbia - Brkić et al. 2010) which, following Roberts et al. (2001) we explain by a positive correlation between the level of steroid hormones (testosterone) and susceptibility to many infections including toxoplasmosis.

Latent toxoplasmosis manifested by Toxoplasma seropositivity might not be neutral for the human organism; this was mostly shown in the studies by Flegr et al. (1996, 2002, 2003, 2005) and Havlíček et al. (2001). They showed that such form of toxoplasmosis could in- 
fluence some personality traits, psychomotor performance and morphological features. Whereas those authors demonstrated correlation between latent toxoplasmosis and some traits among adults, our study was focused on children, on their motor performance, morphological characteristics and the level of biological development with reference to toxoplasmosis. Since Toxoplasma seropositivity found in schoolchildren from Grzebienisko was rather high, we were able to compare the levels of body mass and body height, developmental age of body mass and body height, EMN developmental age, physical fitness and school performance between children who were Toxoplasma-seropositive and seronegative. In earlier studies, only morphological characteristics in connection with toxoplasmosis were analysed and only in adults. It was noticed that the infected men had higher body heights than the non-infected, but the finding was not recognized as biologically significant considering that this trait correlates positively with the testosterone level (Flegr et al. 2005).

There was no significant difference between seropositive and seronegative children (either boys or girls) as regards morphological features so it could be concluded that Toxoplasma has small, if any, influence on these characteristics in children at the stage of maturation, when the traits are shaped most dynamically under the influence of many internal and external factors. The absence of differences in morphology of seropositive and seronegative boys observed in our study could confirm the hypothesis reported by Flegr et al. (2005) that testosterone (produced by the testes in adult men, but not in children) is responsible for higher body height of infected men.

The EMN-index and EMN developmental age differ significantly between the Toxoplasma-seropositive and seronegative only in girls. This could be explained in two ways: either infections by the parasite caused an increased activity of the host organism, which was manifested through its faster development (faster aging), or the parasite has a predilection to organisms that are more advanced in their development as expressed by a higher level of biological age. Such a phenomenon was not observed in boys, but this could be connected with their lower number ( 78 boys versus 112 girls). It is worth noticing that a similar phenomenon was observed in rural children, for girls and boys aged 13-17 years infected with Toxocara (see Jarosz et al. 2010).

In Toxoplasma infection, dormant forms of bradyzoites mostly stay in the neural and muscular tissues of the intermediate hosts. Observation, first of laboratory animals and then of infected people, indicated that latent toxoplasmosis may influence a reaction time, personality profile and bipolar disorder status. It can also cause lower psychomotor agility as seen in longer reaction time (see Introduction). The existence of such connection in adults made us look for a similar relationship in children. The lack of significant correlation between seropositivity and the physical fitness abilities in children is difficult to give an unequivocal interpretation, particularly as we do not know when exactly the examined persons came into contact with the parasite.

It should also be remembered that the parasite always leads to the formation of antibodies remaining in the human body till the end of life. It is also known that sensitivity to the shaping of specific psychomotor features changes throughout ontogenesis. Also in toxocarosis there was no connection between the level of fitness and seropositivity of children (Jarosz et al. 2010). Although these two zoonotic parasites (T. gondii and Toxocara spp.) differ considerably, both stimulate the organism of the host to an immune response and the connection between the immune system and ontogenetic development has already been described (Wolański 2006).

We studied a possible cognitive impairment of the examined children with regard to toxoplasmosis on the basis of their grades at school. The end-of-year grades were higher for girls than for boys and only among girls latent toxoplasmosis had visible correlation to their school grades. This observation is difficult to interpret but we can speculate that the reaction to the parasite differs depending on the gender and/or the localization of the parasite in the cells of the host. It is possible that in the infected girls, more frequently than boys, $T$. gondii was located in the cells of neural system, disturbing its functioning.

For the first time we analysed the association between the serological titre and various factors (morphological features, developmental age, physical fitness abilities and school performance) to observe the possible cumulative correlation of latent toxoplasmosis or transient correlation of acute toxoplasmosis on the examined features. However, neither positive nor negative correlation between them was found.

There are contradicting opinions about how the infection with $T$. gondii is acquired by humans; a majority of parasitologists assume that the main source is raw or poorly cooked meat containing cysts rather than soil contaminated with oocysts (Tenter et al. 2000, Kim and Weiss 2008). This view is based on the observation that a very small proportion of cats (about $1 \%$ ) is infected, and that the shedding of oocysts in the environment occurs in a short period of their lives (Robertson et al. 2000). However, this opinion is dubious in view of the fact that a high rate of Toxoplasma seroprevalence was observed among some populations of vegetarians (Tenter et al. 2000). Recently, Kolbeková et al. (2007) reported that eating raw rabbit meat can be an equally important risk factor as farming and contact with cat feces. Although many raw meat products were recognized as risk factors for Toxoplasma infection, the results of our study suggest that boys acquire toxoplasmosis rather by eating raw meat, whereas girls through contact with cats. This may be ex- 
plained by differences in gender behaviour, especially by the fact that girls more often pet their cats. In rural areas of Poland (Wielkopolska district) soil contaminated with cat faeces occurred to be an important source of child toxoplasmosis which was earlier suggested in the region by Szewczyk-Kramska (1999).

The lack of connection between Toxoplasma seroprevalence and keeping cats in the household could indicate that stray cats strongly contaminate soil thus increasing the prevalence of Toxoplasma oocysts and the risk of infection (see also Taylor et al. 1997).

We can conclude that in the village of Grzebienisko school children are infected with $T$. gondii frequently but the infections are asymptomatic. Such infections have small, if any, influence on their general biological condition measured by morphological characteristics, physical fitness and cognition abilities (performance at school). The most interesting phenomenon observed was a connection between Toxoplasma infection and the level of biological development measured with the EMN index and EMN development age. However, this subject deserves further in-depth research, taking into consideration gender differences.

Acknowledgments. This study was supported by an internal research project grant of the University School of Physical Education in Poznan, Poland. We are deeply grateful to the children, their parents and the head of the school in Grzebienisko for their consent to participate.

\section{REFERENCES}

Brkić S., Gajski G., Bogavac M., Marić D., Turkulov V., Tоміс́ S. 2010: [Seroprevalence of toxoplasmosis in Vojvodina]. Srp. Arh. Celok. Lek. 138: 333-336. (In Serbian.)

CZapla Z., Cieślik J. 1998: The electrophoretic mobility of cell nuclei (EMN) index - relation to biological and physical properties of the cell. Anthropol. Rev. 61: 93-101.

Dubey J.P. 1998: Advances in the life cycle of Toxoplasma gondii. Int. J. Parasitol. 28: 1019-1024.

FLEGR J. 2010: Influence of latent toxoplasmosis on the phenotype of intermediate hosts. Folia Parasitol. 57: 81-87.

Flegr J., Havlíček J., Kodym P., Malý M., Šmahel Z. 2002: Increased risk of traffic accidents in subjects with latent toxoplasmosis: a retrospective case-control study. BMC Infect. Dis. 2: 11 .

Flegr J., Hrušková M., Hodný Z., Novotná M., Hanušová J. 2005: Body height, body mass index, waist-hip ratio, fluctuating asymmetry and second to fourth digit ratio in subjects with latent toxoplasmosis. Parasitology 130: 621-628.

Flegr J., Kodym P., Tolarová V. 2000: Correlation of duration of latent Toxoplasma gondii infection with personality changes in women. Biol. Psychol. 53: 57-68.

Flegr J., Preiss M., Klose J., Havlíček J., Vitáková M., Kody P. 2003: Decreased level of psychobiological factor novelty seeking and lower intelligence in men latently infected with the protozoan parasite Toxoplasma gondii Dopamine, a missing link between schizophrenia and toxoplasmosis? Biol. Psychol. 63: 253-268.

Flegr J., Zítková S., Kodym P., Frynta D. 1996: Induction of changes in human behaviour by the parasitic protozoan Toxoplasma gondii. Parasitology 113: 49-54.

Goldman M. 1957: Staining Toxoplasma gondii with fluoresceinlabelled antibody. II. A new serologic test for antibodies to Toxoplasma based upon inhibition of specific staining. J. Exp. Med. 105: 557-573.

Gutierrez J., Roldan C., Maroto M.C. 1996: Seroprevalence of human toxoplasmosis. Microbios 85: 73-75.

Havlíček J., Gašová Z., Smith A.P., Zvara K., Flegr J. 2001: Decrease of psychomotor performance in subjects with latent "asymptomatic" toxoplasmosis. Parasitology 122: 515-520.

Hay J., Aitken P.P., Hair D.M., Hutchison W.M., Graham D.I. 1984: The effect of congenital Toxoplasma infection on mouse activity and relative preference for exposed areas over a series of trials. Ann. Trop. Med. Parasitol. 78: 611-618.
Huldt G., Lagercrantz R., Sheehe P.R. 1979: On the epidemiology of human toxoplasmosis in Scandinavia especially in children. Acta Paediatr. Scand. 68: 745-749.

Hutchinson W.M., Bradley M., Cheyne W.M., Wells B.W., HAY J. 1980: Behavioural abnormalities in Toxoplasma-infected mice. Ann. Trop. Med. Parasitol. 74: 337-345.

Jarosz W., Mizgajska-Wiktor H., Kirwan P., Konarski J., RyChlicki W., Wawrzyniak G. 2010: Developmental age, physical fitness and Toxocara seroprevalence amongst lower-secondary students living in rural areas contaminated with Toxocara eggs. Parasitology 137: 53-63.

Jones J.L., Kruszon-Moran D., Won K., Wilson M., Schantz P.M. 2008: Toxoplasma gondii and Toxocara spp. co-infection. Am. J. Trop. Med. Hyg. 78: 35-39.

Kim K., Weiss L.M. 2008: Toxoplasma: the next 100 years. Microbes Infect. 10: 978-984.

Kolbeková P., Kourbatová E., Novotná M., Kodym P., Flegr J. 2007: New and old risk-factors for Toxoplasma gondii infection: prospective cross-sectional study among military personnel in the Czech Republic. Clin. Microbiol. Infect. 13: 1012-1017.

Leogrande G. 1992: Studies on the epidemiology of child infections in the Bari area (south Italy). V. Epidemiology of Toxoplasma gondii infections. Microbiologica 15: 237-241.

Mohan B., Dubey M.L., Malla N., Kumar R. 2002: Seroepidemiological study of toxoplasmosis in different sections of population of Union Territory of Chandigarh. J. Commun. Dis. 34: $15-22$.

Roberts C.W., Walker W., Alexander J. 2001: Sex-associated hormones and immunity to protozoan parasites. Clin. Microbiol. Rev. 14: 476-488.

Robertson I.D., Irwin P.J., Lymbery A.J., Thompson R.C.A. 2000: The role of companion animals in the emergence of parasitic zoonoses. Int. J. Parasitol. 30: 1369-1377.

Rodrigues I.M., Castro A.M., Gomes M.B., Amaral W.N., Avelino M.M. 2009: Congenital toxoplasmosis: evaluation of serological methods for the detection of anti-Toxoplasma gondii IgM and IgA antibodies. Mem. Inst. Oswaldo Cruz 104: 434-440.

Shakhbazov V.G., Colupaeva T.V., Nabokov A.L. 1986: [New method for determining the biological age of humans.] Lab. Delo 7: 404-407. (In Russian.) 
Shakhbazov V.G., Grigoreva N.N., Colupaeva T.V. 1996: [A new cyto-biophysical index of biological age and the physiological state of the human body.] Fiziol. Cheloveka 22: 71-75. (In Russian.)

Stinson S., Bogin B., Huss-Ashmore R., O’Rourke D. (Eds.) 2000: Human Biology: An Evolutionary and Biocultural Perspective. Wiley-Liss, New York, 656 pp.

SzeWCZYK-KRAMSKa B. 1999: [Toxoplasmosis and toxocarosis in children from Wielkopolska]. Now. Lekarskie 68: 621-632. (In Polish.)

Taylor M.R, Lennon B., Holland C.V., Cafferkey M. 1997: Community study of Toxoplasma antibodies in urban and rural schoolchildren aged 4 to 18 years. Arch. Dis. Child. 77: 406-409.

Tenter A.M., Heckeroth A.R., Weiss L.M. 2000: Toxoplasma gondii: from animals to humans. Int. J. Parasitol. 30: 1217-1258 (with erratum in Int. J. Parasitol. 31 (2001): 217-220).
Thomas D.R., Salmon R.L., Lewis G., Smith A.P. 2004: Toxoplasma and Coxiella infection and psychiatric morbidity: a retrospective cohort analysis. BMC Psychiatry 4: 32 .

Torrey E.F., Yolken R.H. 2003: Toxoplasma gondii and schizophrenia. Emerg. Infect. Dis. 9: 1375-1380.

Wachowski E., Strzelczyk R., Osiński W. 1987: [Measurement of Motor Fitness in Individuals Practicing Sport: Results of Research]. Monografia AWF Poznań, No. 238, 153 pp. (In Polish.)

Walker J., Nokes D.J., Jennings R. 1992: Longitudinal study of Toxoplasma seroprevalence in South Yorkshire. Epidemiol. Infect. 108: 99-106.

Webster J.P., Brunton C.F., MacDonald D.W. 1994: Effect of Toxoplasma gondii upon neophobic behaviour in wild brown rats, Rattus norvegicus. Parasitology 109: 37-43.

Wolański N. 2006: [Biological Development of Human: Bases of Auxology, Gerontology and Health Promotion]. Seventh Edition. Wydawnictwo Naukowe PWN, Warszawa, 545 pp. (In Polish.)

Accepted 24 May 2013 